\title{
Spatial and temporal distribution of thermotolerant coliform in Canal de Passagem (Vitória - ES) - related to physico-chemical parameters and tide
}

\author{
Mariana Magnago Alves*, Gilberto Fonseca Barroso, Renato Rodrigues Neto
}

\author{
Departamento de Oceanografia da Universidade Federal do Espírito Santo. \\ (Av. Fernando Ferrari, nำ 514, Vitória, ES, Brazil, CEP: 29075-910) \\ *Corresponding author: alvesmm.oceano@gmail.com \\ Financial Support: FACITEC - Fundo de suporte à Ciência e Tecnologia da Cidade de Vitória, no financiamento das coletas.
}

\begin{abstract}
The Canal de Passagem (CP), Vitória - ES, is an estuarine system undergoing a process of environmental degradation due to the discharge of in natura and semi-treated sewage. The surrounding local community's use of the estuarine resources conflicts with environmental quality and this offers risks to public health. The objective of this study was 1. to evaluate the distribution of fecal coliforms in the HCP (multiple tubes method), relating it to the distribution of sources of fecal pollution, the dynamics of the tides and physico-chemical parameters, and 2. evaluate the results in the light of the limits established by Brazilian legislation to ensure the health of the users of the water whatever the use to which it is put. Samples were taken spatially and temporally, to assess the tidal cycle of the spring tide in the winter, autumn and spring seasons, and also of the neap and spring tides at two sampling events in the summer. The sanitary parameters thermotolerant coliforms, physico-chemical, and tidal action, were considered. Meaningful correlations were found with the tidal regime. As conclusion, that the distribution of thermotolerant coliforms was related to the point sources of pollution, and the concentrations were different between spring and neap tides. This difference between tides is not taken into consideration by the Brazilian Bathing Water Legislation up to now.
\end{abstract}

Descriptors: Thermotolerant coliforms, Estuary, Tide, Physico-chemical parameters, Water quality.

\section{Resumo}

O Canal de Passagem, Vitória, ES, é um sistema estuarino em processo de degradação ambiental devido à descarga de esgoto in natura e semitratado. Os usos da comunidade do entorno dos recursos locais estuarinos são conflitantes com a qualidade ambiental, o que pode oferecer riscos para a saúde pública. Os objetivos do presente trabalho foram: 1. avaliar a distribuição de coliformes termotolerantes dentro do HCP (método dos tubos múltiplos), relacionando-a com a distribuição das fontes de poluição fecal, a dinâmica de marés e parâmetros físico-químicos, e 2. avaliar os resultados dentro das leis brasileiras de limites sanitários para os variados usos da água e balneabilidade. Amostras foram feitas espacialmente e temporalmente, visando cobrir o ciclo de marés de sizígia no inverno, outono e primavera, e também cobrindo uma quadratura e uma sizígia na amostragem no verão. Foram considerados os parâmetros sanitários - coliformes termotolerantes, físicos e químicos e a ação das marés. Correlações significativas foram encontradas com o regime das marés e distribuição de coliformes. A conclusão retirada do trabalho foi que a distribuição de coliformes termotolerantes esteve relacionada com as fontes pontuais de poluição, e as concentrações foram diferentes entre as marés de quadratura e sizígia. Variação entre tais marés não é observada até o momento pela Legislação Brasileira para as águas balneáveis.

Descritores: Coliformes termotolerantes, Estuário, Maré, Parâmetros físico-químicos, Qualidade de água. 


\section{INTRODUCTION}

The intensive multiple human uses of the environmental resources of the Baía Vitória and Canal de Passagem (CP) estuarine system (metropolitan area of Vitória, ES) is harmful to the sanitary quality of the water. The direct contact with the contaminated water used for bathing and the consumption of contaminated seafood pose a health risk for local communities that rely on these natural resources for subsistence.

Enteric microorganism contamination is the major concern because a high concentration of them is found in the PW waters, despite their decaying in the external environment. The bactericidal effects of natural waters result from the synergic effects of biotic and abiotic factors such as salinity (BURKHARDT III et al., 2000; DIONÍSIO et al., 2000; MILL et al., 2006; PORTNOY et al., 2006), turbidity, dissolved oxygen (CURTIS et al., 1992; DIONÍSIO et al., 2000;), sedimentation and flocculation (RODRIGUES et al., 2011), toxins (SMITH et al., 1994), solar radiation (principally UV radiation) (SINTON et al., 2002), temperature (SINTON et al., 1994; Burkhardt III et al., 2000), pH (CURTIS et al., 1992; SINTON et al., 1994) and rainfall (CRABILL et al., 1999; KISTEMANN et al., 2002).

Estuaries present characteristics predominantly of spatial and temporal change in the physico-chemical environment by virtue of tidal action (ELLIOT; MCLUSKY, 2002). The relationships between tidal cycles and the variability of water quality has been highlighted in some estuarine studies (DOYLE et al.,1992; COELHO et al., 1999; MALLIN et al., 1999; MILL et al., 2006; and others).

The objective of the study was to investigate possible patterns of the spatial and temporal distribution of fecal contamination by thermotolerant coliforms by means of an environmental monitor, and supported by reference to physico-chemical parameters and tidal action, comparing the results with the limits established by Brazilian Legislation of Quality for Bathing and limits of toleration for other human uses of water. This study is a part of a multidisciplinary integrated research Project supported by a 2007 research grant of the Municipality Fund for Research and Technology of Vitória - FACITEC.

\section{MATERIAL AND METHODS}

The estuarine system of Canal de Passagem (775500077562000; 362100-365700 UTM, datum SAD69) is associated with an extensive mangrove swamp of approximately $20 \mathrm{~km}^{2}$ known as the Lameiro Island which is a partially protected municipal conservation area and serves as a habitat for crustaceans, mollusks, birds, and mammals.

In the mangrove area of the $\mathrm{CP}$, natural resources extractivism is a very important source for subsistence and also for small commercial activities. Extractive resources are food (e.g., crabs, oysters and mussels), firewood, and tannins for the manual production of adobe pans.

Environmental changes have been related to the input of raw sewage through the pluvial drainage system and partially treated effluents from wastewater treatment plants. The connection of the PW to the southern section of Camburí Beach, which is important as a recreational site for the City of Vitória, makes this beach of unsuitable quality for bathing.

Aggravating the hydrodynamic setting of the $\mathrm{CP}$, the presence of a barotropic convergence zone increases the water residence time in the area.

The tidal regime in the estuarine system is half daytime lunar micro-tidal (maximum amplitude $0.9 \mathrm{~m}$ in neap tide and $1.7 \mathrm{~m}$ at the spring tide). In the $\mathrm{CP}$ there exists an asymmetry of the ebb tide that predominates during the spring tides, while a reduction or inversion occurs in the neap tides. The principal harmonic compound is M2, with a period of $12.4 \mathrm{~h}$.

The three first sampling events were carried out to assess the seasonal variability of the spring tidal cycles at five sites (Figure 1) along the longitudinal axis of the $\mathrm{PW}$, of the maximum and minimum heights of water level: autumn (03-25-08, tidal amplitude $1.1 \mathrm{~m})$; winter (07-2308 , tidal amplitude $1.2 \mathrm{~m})$ and spring (10-31-08, tidal amplitude $1 \mathrm{~m}$ ). Due to logistical problems the summer sampling was carried out only at S3. However, the diurnal hourly samplings were carried out during the neap and spring tidal cycles, respectively, on 03-02-09 (0.9m tidal amplitude) and 03-27-09 (1.4m tidal amplitude).

Sampling site 1 (S1) presents the connection of $\mathrm{CP}$ with the Espírito Santo Bay, on Camburí Beach. S1 is impacted by in natura wastewater from the neighboring areas. $\mathrm{S} 2$ is also highly impacted by in natura wastewater as well by pluvial inputs. S3 is located next to the Federal University campus of Goiabeiras and is less influenced by direct wastewater and pluvial outflows. S4 is highly affected by raw sewage from the Maria Ortiz neighborhood and by semi-treated sewage from the Camburí neighborhood's wastewater treatment plant. S5 is the reference sample site, not affected by direct sources of sewage. 


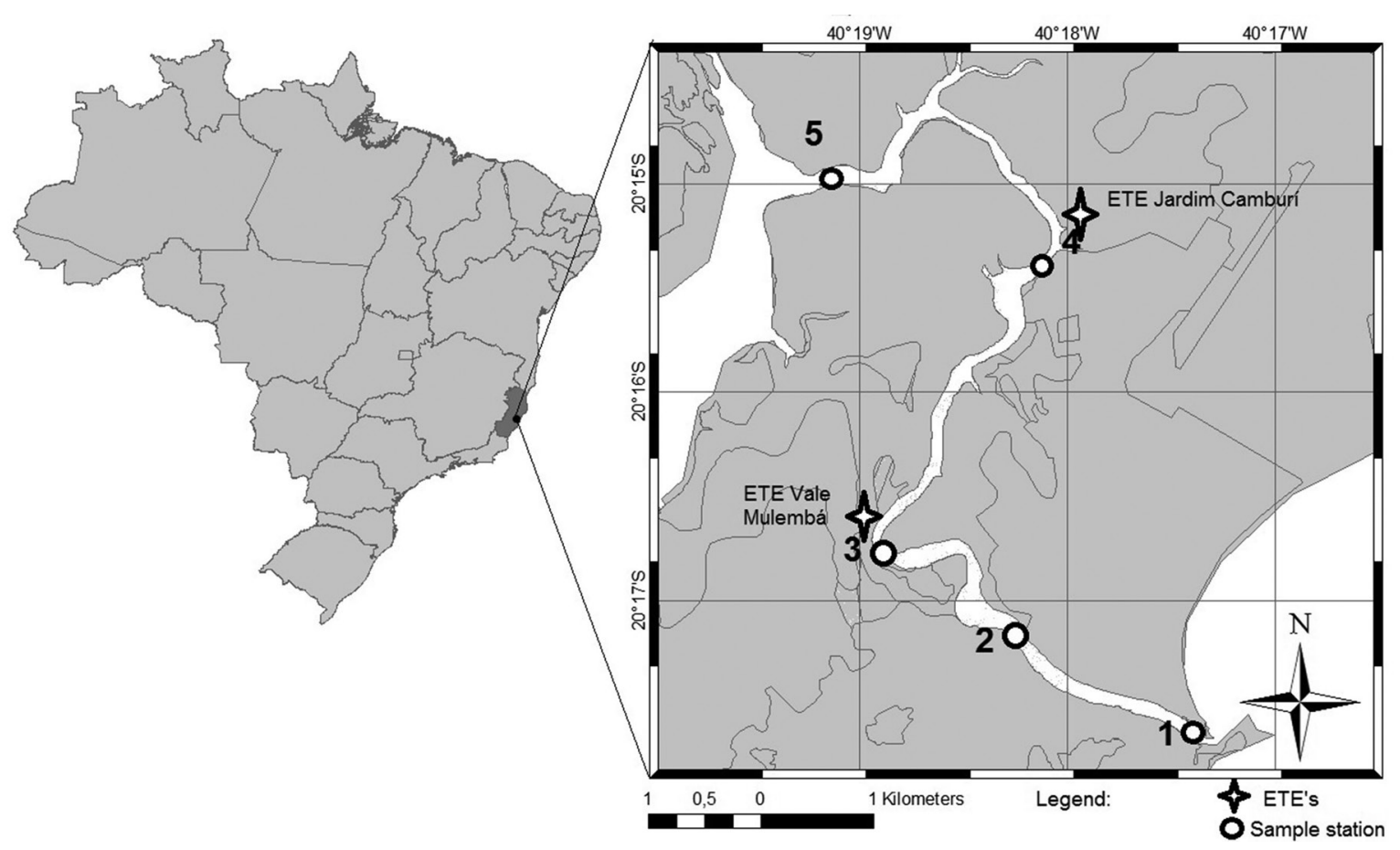

Figure 1. Samples sites numbered and the local of discharge the effluent of sewage treatment plants (ETE's).

Tidal heights were obtained from the tidal records of Tubarão Port (Vitória, ES), based on the Tide Tables of the Directorate of Hydrography and Navigation (DHN) of the Brazilian Navy. To integrate tidal data, relative tidal amplitude was used as a linear function of time.

Water samples were collected below the surface of the water column in autoclaved polyethylene containers $(150 \mathrm{~mL})$.

The analytical procedure for thermotolerant coliform was based on the 24-hour assay of the multiple tube method, using series of 5 tubes, with A1 medium $\left(\operatorname{Merck}^{\circledR}\right)$, dilutions of up to 10-4 $\mathrm{ml}$ and results expressed as most probable numbers (MPN/100mL) as cited in CLESCERI et al. (1998).

The physico-chemical parameters (i.e., temperature, dissolved oxygen, $\mathrm{pH}$, redox potential, conductivity, and total dissolved solids) were measured in the subsuperficial waters by specific electrodes of Instrutemp ${ }^{\circledR}$, and laboratory analysis.

Current data were measured by an ADP device Nortec $2 \mathrm{MHz}$, deployed at S3.

Rainfall was based on A-612 INMET (Brazilian Institute of Meteorology), a meteorological station located in the University campus.

The statistical analysis used Linear and Spearman correlations with $p<0.05$, and an ANOVA test was applied for coliform concentrations, comparing sampling events and sites, and spring and neap tides.

\section{RESULTS}

\section{SPATIAL AND SEASONAL CAMPAIGNS (WINTER, AUTUMN AND SPRING)}

The thermotolerant coliform concentrations in the seasonal samplings are given in Table 1 . The highest concentration $(1.5 \times 105 \mathrm{MPN} / 100 \mathrm{ml})$ was found at $\mathrm{S} 2$, and the lowest ( $\leq 26 \mathrm{MPN} / 100 \mathrm{ml}$ ) at $\mathrm{S} 5$, both during the low tides of the spring season. Neither Spearman's nor linear correlations with physico-chemical parameters occurred. The linear correlations between changes in tidal height and the bacterial concentration at $\mathrm{S} 1$ presents $\mathrm{R}^{2}=-0.54$; at $\mathrm{S} 2$, $\mathrm{R}^{2}=-0.20$; at $\mathrm{S} 3, \mathrm{R}^{2}=0.77$; at $\mathrm{S} 4 \mathrm{R}^{2}=-0.80$; and at $\mathrm{S} 5$, $\mathrm{R}^{2}=0.61$. The ANOVA test found a significant temporal change in samples only at $\mathrm{S} 4$, with $p=0.007$.

\section{TIDAL DAYTIME CYCLE PERIOD CAMPAIGN DURING NEAP AND SPRING TIDES (SUMMER)}

The concentrations of coliforms at neap tide varied between $7.5 \times 102$ (7:42 and 11:42) and 2.4 x $104(15: 42)$ NMP/100 $\mathrm{ml}$ (Table 2), and the low concentrations were related to the mean levels of tides, correspondence of the 
Table 1. Spatial and seasonal thermotolerant coliform densities (MPN/100mL).

\begin{tabular}{lllllll}
\hline & \multicolumn{2}{c}{ Autumn } & \multicolumn{2}{c}{ Winter } & \multicolumn{2}{c}{ Spring } \\
\hline & Low tide & High tide & Low tide & High tide & Low tide & Hight tide \\
S1 & $2.8 \times 10^{4}$ & $3.0 \times 10^{3}$ & $9.3 \times 10^{4}$ & $9.3 \times 10^{3}$ & $9.3 \times 10^{3}$ & $9.3 \times 10^{2}$ \\
S2 & $8.0 \times 10^{4}$ & $3.0 \times 10^{4}$ & $1.5 \times 10^{4}$ & $2.4 \times 10^{3}$ & $1.5 \times 10^{5}$ & $1.5 \times 10^{3}$ \\
S3 & $8.0 \times 10^{2}$ & $8.0 \times 10^{4}$ & $4.3 \times 10^{2}$ & $9.3 \times 10^{3}$ & $2.4 \times 10^{3}$ & $2.4 \times 10^{4}$ \\
S4 & $5.0 \times 10^{3}$ & $3.4 \times 10^{2}$ & $7.5 \times 10^{4}$ & $2.4 \times 10^{3}$ & $9.3 \times 10^{3}$ & $1.5 \times 10^{2}$ \\
S5 & $2.4 \times 10^{2}$ & $9.0 \times 10^{3}$ & $4.0 \times 10^{1}$ & $1.5 \times 10^{2}$ & $\leq 26$ & $9.3 \times 10^{2}$ \\
\hline & & & & & &
\end{tabular}

Table 2. Summer tidal cycle thermotolerant coliform density (MPN/100mL) at S3.

\begin{tabular}{cccc}
\hline \multicolumn{2}{c}{ Neap tide } & \multicolumn{2}{c}{ Spring tide } \\
\hline Sampling time & MNP/100ml & Sampling time & MNP/100ml \\
\hline $07: 42$ & $7.5 \times 10^{2}$ & $08: 25$ & $2.1 \times 10^{3}$ \\
$08: 42$ & $1.5 \times 10^{3}$ & $10: 12$ & $2.4 \times 10^{3}$ \\
$09: 42$ & $9.3 \times 10^{2}$ & $11: 18$ & $1.4 \times 10^{4}$ \\
$10: 42$ & $9.3 \times 10^{2}$ & $12: 35$ & $9.3 \times 10^{3}$ \\
$11: 42$ & $7.5 \times 10^{3}$ & $13: 27$ & $2.1 \times 10^{4}$ \\
$12: 42$ & $4.6 \times 10^{3}$ & $14: 23$ & $4.6 \times 10^{4}$ \\
$13: 42$ & $1.1 \times 10^{4}$ & $15: 23$ & $1.1 \times 10^{4}$ \\
$14: 42$ & $4.6 \times 10^{3}$ & $16: 23$ & $9.3 \times 10^{3}$ \\
$15: 42$ & $2.4 \times 104$ & $17: 23$ & $4.6 \times 10^{4}$ \\
$16: 42$ & $2.4 \times 10^{3}$ & $18: 23$ & $2.4 \times 10^{4}$ \\
$17: 42$ & $1.1 \times 10^{4}$ & $19: 23$ & $9.3 \times 10^{3}$ \\
$18: 42$ & $4.6 \times 10^{3}$ & $20: 23$ & $4.6 \times 10^{3}$ \\
\hline
\end{tabular}

inflection points of tidal waves (flood and ebb tide - where there was movement and possible renewal of water) and the maximum in the moment of the lowest tide level of low tide (less dilution by the seawater).

During the spring tide, the concentrations of coliforms varied between $2.1 \times 103$ (8:25 am) and $4.6 \times 104$ (12:42 and 15:42 pm) NMP/100ml. The minimum value was near to the time of the apex of low tide and the maximum near to the time of the inflection point of the wave of high tide (ebb tide).

In the tidal cycle, the campaigns only presented significant correlations between coliform density and temperature during the spring tide, $\mathrm{R}^{2}=0.64(\mathrm{~N}=10$; $p=0.046$ ).

For the tide, the Spearman correlation for neap tide in relation of MPN/100ml was $\mathrm{R}^{2}=-0.69(\mathrm{~N}=12 ; p<0.011)$ and spring tide $\mathrm{R}^{2}=0.65(\mathrm{~N}=12 ; p=0.021)$. The spring tide showed higher concentrations of thermotolerant coliforms than did the neap tide, and the oxygen concentration was also lower, approaching hypoxia levels $(3.10 \pm 0.87 \mathrm{mg} / \mathrm{l})$.

\section{DISCUSSION}

The spatial settings of the point sources of pollution, the hydrodynamic complexity of the $\mathrm{CP}$ and the inherent physico-chemical gradients of the estuary related to the decay of enteric bacteria, meant that spatial changes in the coliform concentration were to be expected.

Results confirmed this expectation for S2, the site most affected by direct fecal contamination because of its proximity to pollution sources, and for S5, the least affected, as being further away.

In relation to tides, at $\mathrm{S} 1, \mathrm{~S} 2$ and $\mathrm{S} 4$, near waste water sources, the coliform concentrations were higher at low tide, demonstrated by the inverse linear correlation with the amplitude tidal change. During low tide, a smaller seawater volume enters the channel, and the concentrations are therefore less diluted. Moreover, the sewage outflows at intertidal sites are exposed, and the pressure gradient is favorable to the discharge. This pattern is similar to that described by other estuarine shallow water studies (MILL et al., 2006; PORTNOY et al., 2006; RODRIGUES et al., 2011; LIU et al., 2015), where much higher salinity and lower coliform concentrations were found, the seawater thus limiting the coliform concentrations both by stress and dilution.

At S3 and S5, at the greatest distances from sources of fecal contamination, the trend is different (positive linear correlation). This may indicate that the effluents from the wastewater treatment station of Vale Mulembá and in natura effluents are being transported from S2 to $\mathrm{S} 3$ at high tide. This hypothesis is supported by the physico-chemical parameters pertaining in autumn and winter. Values of conductivity and dissolved oxygen were lower and the total ammoniac nitrogen was higher during high tides, indicating fresher and more contaminated water, respectively. Current data in spring indicate a resulting flow from S2 to S3 during high tide. During the neap tidal cycle a tendency to an inverse relation ( $\mathrm{R}^{2}$ negative) between bacterial concentration and tidal amplitude occurred, the same occurring during spring tide.

Near-hypoxia conditions were observed at spring tide during the cycle sampling event than occurred at S3, which may represent the presence of more wastewater in the environment, confirming the great coliform density. The trend to inverse ( $\mathrm{R}^{2}$ negative) coliform concentration with tidal amplitude, may reflect the presence of in situ sources of fecal pollution, which increases the bacterial concentration at low tide, and its reduction during high 
tide may mean that the pollution at S2 would not be reaching S3 as a result of the lower tidal current velocities and lower tidal amplitude.

At S5, the water during high tide was fresher and less contaminated, as it probably comes from the Santa Maria River (based on lower $\mathrm{pH}$ values during high tides and an absence of other sources of fresh water). The Santa Maria River flow may affect the PW's hydrodynamics (water enters by both extremities of the channel as a tidal wave) generating the barotropic convergence zone.

Probably because of the absence of significant rainfall before the sampling events, seasonal variation was scarcely of any significance. In relation to the sampling sites, only S4 presents significant seasonality (ANOVA, $p=0.007$ ). Considering the sampling seasons, the autumn presented a subtly higher concentration of coliforms, but this did not obey a specific pattern.

Single peaks were found during the sampling cycle of the spring and neap tides but no pattern was detected. Another estuarine study (PORTNEY et al., 2006), was similarly conducted, taking into account a 12-hour tidal cycle of spring and neap tides, and found the same result.

In accord with CONAMA 357 (2005), the CP waters were classified predominantly in class 3 , i.e. as brackish waters. In this class, the legislation says that TC concentration should not exceed 4.0 x $103 \mathrm{MPN} / 100 \mathrm{ml}$ in $80 \%$ of a minimum of six time samples collected bimonthly during a year. Although the present study did not maintain this periodicity, the criterion for classification was that $80 \%$ of the samples should not exceed $4.0 \times 103$ MPN/100ml of TC. In the CONAMA 357 legislation, the uses permitted for class 3 waters are navigation and landscaping harmony. Only S5 presents less than $80 \%$ of its samples with $2.5 \times 10^{3} \mathrm{MPN} / 100 \mathrm{ml}$ Thermotolerant Coliform (TC), and our classification in terms of the CONAMA 357 legislation was class 2, and the uses allowed included amateur fishing and secondary contact recreation.

In accordance with the CONAMA 357 Resolution, the water of the Canal de Passagem is unsuitable for most noble human uses, considering that more than $80 \%$ of the samples presented concentrations higher than $4.0 \times 103$ thermotolerant coliforms MPN/100mL, except for S5, and would therefore be classified as class 2, destined for amateur fishing and secondary contact recreation.
The CONAMA 274 resolution states water is improper for bathing if more than $80 \%$ of the samples have more than $1.0 \times 10^{3} \mathrm{MPN} / 100 \mathrm{ml}$, or when the concentration at the last sampling was higher than $2.5 \times 10^{3} \mathrm{MPN} / 100 \mathrm{ml}$ so only S5 is proper for bathing in the winter (excellent quality) and in the spring (satisfactory quality). However, this legislation did not take the tidal factor into account, and considers only the period of greater frequency of bathers, which can lead to an incorrect classification of the area. In conclusion, the sampling the sampling methodology used as the basis for Brazilian law should take the tidal cycle into consideration, and could add other environmental indicators of the quality of water.

We would recommend to the competent authorities that the mapping and control of the pluvial and sewage discharges in the area here described should be updated. The volume volume of sewage treated has been incresead and far exceeded the ability of the environment to recycle these effluents.

\section{ACKNOWLEDGEMENTS}

The authors wish to thank the Fund for the Support of Science and Technology of Vitória - FACITEC for providing the financial support to all participants and especially the students of UFES Oceanography Undergraduate Program for their colaboration in the sampling campaigns and laboratory analyses.

\section{REFERENCES}

BURKHARDT III, W.; CALCI, K. R.; WATKINS, D. W.; RIPPEY, S. R.; CHIRTEL, S. J. Inactivation of indicator microorganisms in estuarine waters. Water. Res., v. 34, n. 8, p. 2207-2214, 2000.

CLESCERI, L. S.; EATON, A. D.; GREENBERG, A. E. Standard methods for the examination of water and wastewater. Washington: APHA/AWW/WEF, 1998. 1325 p.

COELHO, M. P. P.; MARQUES, M. E.; ROSEIRO, J. C. Dynamics of microbiological contamination at a marine recreational site. Mar. Pollut. Bull., v. 38, n. 12, p.1242-1246, 1999.

CRABILL, C.; DONALD, R.; SNNELING, J.; FOUST, R.; SOUTHAM, G. The impact of sediment fecal coliform reservoirs on seasonal water quality in Oak Creek, Arizona. Water. Res., v. 33, n. 9, p. 2163-2171, 1999.

CURTIS, T. P.; DUNCAN, M. D.; SILVA, S. A. Influence of $\mathrm{pH}$, oxygen, and humic substances on ability of sunlight to damage fecal coliforms in waste stabilization pond water. Appl. Environ. Microbiol., v. 58, n. 4, p.1335-1343, 1992. 
DIONÍSIO, L. P. C.; RHEINHEMER, G.; BORREGO, J. J. Microbiological pollution of Ria Formosa (South of Portugal). Mar. Pollut. Bull., v. 40, n. 2, p.186-193, 2000.

DOYLE, J. D.; TUNNICLIFF, B.; KRAMER, R.; KUEHL, R.; BRICKLER, S. K. Instability of fecal coliform populations in waters and bottom sediments at recreational beaches in Arizona. Water. Res., v. 26, n. 7, p. 979-988, 1992.

ELLIOTT, M.; MCLUSKY, D. S. The need for definitions in understanding estuaries. Estuar. Coast. Shelf Sci., v. 55, n. 6, p. 815-827, 2002.

KISTEMANN, T.; CLABEN, T.; KOCH, C.; DANGENDORF, F.; FISCHEDER, R.; GEBEL, J.; VACATA, V.; EXNER, M. Microbial load of drinking water reservoir tributaries during extreme rainfall and runoff. Appl. Environ. Microbiol., v. 68, n. 5, p. 2188-2197, 2002.

LIU, W. C.; CHAN, W. T.; YOUNG, C. C. Modeling fecal coliform contamination in a tidal Danshuei River estuarine system. Sci. Total Environ., v. 502, p. 632-640, 2015.

MALLIN, A. M.; ESHAM, E. C.; WILliAMS, K. E.; NEARHOOF, J. E. Tidal stage variability of fecal coliform and chlorophyll a concentrations in coastal creeks. Mar. Pollut. Bull., v. 38, n. 5, p. 414-422, 1999.
MILL, A.; SCHLACHER, T.; KATOULI, M. Tidal and longitudinal variation of fecal indicator bacteria in an estuarine creek in south-east Queensland, Australia. Mar. Pollut. Bull., v. 52, n. 8, p. 881-981, 2006.

PORTNOY, J. W.; ALLEN, J. R. Effects of tidal restrictions and potential benefits of tidal restoration on fecal coliform and shellfish-water quality. J. Shellfish. Res., v. 25, n. 2, p. 609617, 2006.

RODRIGUES, M. R.; OLIVEIRA, A.; GUERREIRO, M.; FORTUNATO, A. B.; MENAIA, J.; DAVID, L. M.; CRAVO, A. Modeling fecal contamination in the Aljezur coastal stream (Portugal). Ocean. Dyn., v. 61, n. 6, p. 841-856, 2011.

SINTON, L. W.; DAVIES-OLLEY, R. J.; BELL, R. G. Inactivation of enterococci and fecal coliforms from sewage and meatworks effluents in seawater chambers. Appl. Environ. Microbiol., v. 60, n. 6, p. 2040-2048, 1994.

SINTON, L. W.; HALL, C. H.; LYNCH, P. A.; DAVIESCOLLEY, R. J. Sunlight inactivation of fecal indicator bacteria and bacteriophages from waste stabilization pond effluent in fresh and saline waters. Appl. Environ. Microbiol., v. 68 , n. 3, p. 1122-1131, 2002.

SMITH, J. J.; HOWINGTON, J. P.; MCFETERS, G. A. Survival, physiological response, and recovery of enteric bacteria exposed to a polar marine environment. Appl. Environ. Microbiol., v. 60, n. 8, p. 2977-2984, 1994. 